\title{
Özkaynak Yatırımlarının UFRS 9 Finansal Araçlar Standardı Uyarmca Muhasebeleştirilmesi
}

\author{
Olcay AKÇíN* \\ İlker KIYMETLİ ŞEN**
}

\section{$\ddot{O Z Z T}$}

UFRS 9 Finansal Araçlar standardı 1 Ocak 2018 tarihinde ve sonrasında başlayan hesap dönemlerine uygulanmak üzere UMS 39 Finansal Araçlar: Muhasebeleştirme ve Ölçme standardının yerini almıştır. UFRS 9 Finansal Araçlar standardı finansal araçların nasıl sinıflandırılacağına, ölçüleceğine, hangi koşullarda finansal tablo dışı bırakılacağına ve riskten korunma muhasebesinin nasıl uygulanacağına ilișkin hükümler içermektedir. Bu çalıșmanın amacı özkaynak yatırımlarının UFRS 9 Finansal Araçlar standardı uyarınca muhasebeleştirilmesinin teorik ve pratik olarak açılklanmasıdır. Geçiş.

Anahtar Kelimeler: UFRS, Finansal Araç, Özkaynak Yatırımı, Gerçeğe Uygun Değer,

JEL Siniflandirmasi: M40, M41, M42.

\section{Accounting of Equity Investments In Accordance With IFRS 9 Financial Instruments \\ ABSTRACT \\ IFRS 9 Financial Instruments was issued to supersede IAS 39 Financial Instruments: Recognition and Measurement and is effective for periods beginning on or after 1 January 2018. IFRS 9 Financial Instruments includes requirements for recognition, measurements, derecognition of financial instruments ads hedge accounting. The purpose of this study is to explain the accounting treatment for equity investments in accordance with IFRS 9 Financial Instruments standard theoretically and practically.}

Keywords: IFRS, Financial Instrument, Equity Investment, Fair Value, Transition.

Jel Classification: M40, M41, M42.

Makale Gönderim Tarihi: 21.12.2018

Makale Kabul Tarihi: 25.1.2019

Makale Türü: Kuramsal makale

\footnotetext{
* Dr., Bağımsız Denetçi, Serbest Muhasebeci Mali Müşavir, olcay.akcin@gmail.com, ORCID ID: 00000001-9075-8285.

** Doç. Dr., Serbest Muhasebeci Mali Müşavir, İstanbul Ticaret Üniversitesi, İşletme Fakültesi, ilksen@ticaret.edu.tr, ORCID ID: 0000-0001-6175-3397.
} 


\section{GíRiş}

İşletmeler küresel ekonominin getirdiği zorlu rekabet koşulları nedeniyle mevcuttaki ve gelecekteki nakit akımlarını hedeflerine uygun şekilde devam ettirebilebilmek için finansal araçlardan yararlanmaktadır. Finansal araçların işletmeler tarafından kullanımının yaygınlaşması ile birlikte söz konusu araçların işletmelere olan etkilerinin finansal tablo kullanıcılarına ne şekilde açıklanması gerektiği konusunda tartışmalar yaşanmaktadır. Uluslararası Finansal Raporlama Standartları Kurulu (UMSK) tarafindan yayınlanan Uluslararası Finansal Raporlama Standartları (UFRS), uluslararası finansal raporlama yapan işletmelere finansal tablo hazırlama sürecinde yol gösterici bir rehberdir.

Finansal araçlara ilişkin olarak UMSK tarafından yayınlanmış dört adet standart bulunmaktadır. Bu standartlar UMS 32 Finansal Araçlar: Sunum (IAS 32 Financial Instruments: Presentation), UFRS 7 Finansal Araçlar: Açıklamalar (IFRS 7 Financial Instruments: Disclosures), UMS 39 Finansal Araçlar: Muhasebeleştirme ve Ölçme (IAS 39 Financial Instruments: Recognition and Measurement) ve UFRS 9 Finansal Araçlar (IFRS 9 Financial Instruments)'dır. UMS 32 Finansal Araçlar Sunum standardında finansal araçlara ilişskin bilgilerin sunumuna ilişkin hükümler bulunmaktadır. UFRS 7 Finansal Araçlar: Açıklamalar standardında finansal araçlara ilişkin finansal tablo kullanıcılarına yapılması gereken açılamalar düzenlenmektedir. UMS 39 Finansal Araçlar: Muhasebeleştirme ve Ölçme standardı finansal araçların finansal tabloya alınışı ve finansal tablo dışı bırakılışına ilişkin hükümler içermektedir. Türev araçlara ilişkin muhasebeleştirilme ilkeleri de bu standartta yer bulmuştur. UMS 39 Finansal Araçlar: Muhasebeleştirme ve Ölçme standardına ilişkin olarak finansal araçların sınıflandırılması, ölçümü, değer düşüklügü̈ hükümleri konusunda yapılan eleştiriler neticesinde UMSK UFRS 9 Finansal Araçlar standardını yayınlamışıtır.

UFRS 9 Finansal Araçlar standardı 1 Ocak 2018 tarihinde ve sonrasında başlayan hesap dönemlerine uygulanmak üzere UMS 39 Finansal Araçlar: Muhasebeleștirme ve Ölçme standardının yerini almıştır. UFRS 9 Finansal Araçlar standardı finansal araçların nasıl sınıflandırılacağına, ölçüleceğine, hangi koşullarda finansal tablo dışı bırakılacağına ve riskten korunma muhasebesinin nasıl uygulanacağına ilişkin hükümler içermektedir. Bu çalışmada bir finansal varlık çeşidi olan özkaynak yatırımlarının UFRS 9 Finansal Araçlar standardı uyarınca muhasebeleştirilmesi incelenecek ve örnek uygulama yardımıyla açıklanacaktır.

\section{SINIFLANDIRMA VE ÖLÇME}

UMS 39 Finansal Araçlar: Muhasebeleştirme ve Ölçme standardı uyarınca finansal varlıklar dört kategoride ele alınmaktadır. Bunlar satılmaya hazır finansal varlıklar, vadeye kadar elde tutulacak finansal varlıklar, gerçeğe uygun değer değişimi kar veya zarara yansitılan finansal varlıklar ile kredi ve alacaklar şeklindedir (UMS 39, p. 9). UFRS 9 Finansal Araçlar standardı finansal varlıkların sınıflandırılmasında temel bir değişiklik getirmiş̧ir. Bu bağlamda UFRS 9 uyarınca finansal varlıklar itfa edilmiş maliyeti üzerinden ölçülen finansal varlıklar, gerçeğe uygun değer değişimi kar veya zarara yansıtılan finansal 
varlıklar ve gerçeğe uygun değer değişimi diğer kapsamlı gelire yansitılan finansal varlıklar şeklinde üç kategoride ele alınmaktadır (UFRS 9, p. 4.1.1-4.1.5). UFRS 9 Finansal Araçlar standardının en temel özelliği bir finansal varlığın ne şekilde sınıflandırılacağının belirlenmesi sırasında raporlayan işletmenin "İş Modeli (Business Model)" doğrultusunda hareket edilmesi prensibidir. Standart, UMS 24 İlişskili Taraf Açıklamaları (IAS 24 Related Party Disclosures) standardında tanımlanan kilit yönetici personel tarafından belirlenen iş modelinin esas alınarak finansal varlıkların sınıflandırılması gerektiğini hükme bağlamıştır (UFRS 9, p. B4.1.1). Bir işletmenin finansal varlıklarını yönetmede kullandığ birden fazla iş modeli bulunabilmektedir. Başka bir deyişle bir işletme finansal yatırımlarının bazılarını sözleşmeye dayalı nakit akışlarını tahsil etmek amacıyla; bazılarını alım/satım yapıp gerçeğe uygun değer değişimlerinden kazanç elde etmek amaciyla aktifinde bulundurabilmektedir. Özetle bir finansal varlığın hangi amaçlarla işletme aktifinde bulundurulduğu, sözleşmeye dayalı nakit akışlarının hangi özellikler gösterdiği, söz konusu finansal varlığın sınıflandırma ve ölçme kriterlerini belirlemektedir.

\subsection{Sinıflandırma}

\subsection{1. İtfa Edilmiş Maliyeti Üzerinden Ölçülen Finansal Varlıklar}

UFRS 9 Finansal Araçlar standardı uyarınca bir finansal varlık sözleşmeye bağlı nakit akışlarının tahsil edilmesini amaçlayan bir iş modeli kapsamında elde tutulması ve finansal varlığa ilişkin sözleşme şartlarının, belirli tarihlerde sadece anapara ve anapara bakiyesinden kaynaklanan faiz ödemelerini içeren nakit akışlarına yol açması durumunda itfa edilmiş maliyeti üzerinden ölçülür (UFRS 9, p. 4.1.2). Bir finansal varlığın veya yükümlülüğün itfa edilmiş maliyeti, finansal varlığın veya yükümlülüğün ilk defa finansal tablolara alındığı tutardan, anapara geri ödemeleri düşüldükten sonra, bu tutara ilk defa finansal tablolara alındığındaki tutar ile vadesindeki tutar arasındaki fark üzerinden etkin faiz yöntemi kullanılarak hesaplanan toplam itfa tutarı eklenerek veya düşülerek bulunan tutardır (UFRS 9, p. Ek A). İtfa edilmiş maliyeti üzerinden ölçülen finansal varlıklara ticari alacaklar, tahvil, vb. finansal araçlar örnek olarak verilebilir. Ancak önceki bölümde de belirtildiği üzere ilgili finansal varlığın hangi iş modeline göre işletme aktifinde bulundurulduğu dikkate alınmalıdır. Örneğin bir tahvilin işletme aktifinde bulundurulma nedenine göre itfa edilmiş maliyet yerine gerçeğe uygun değerden ölçümü mümkündür.

\subsubsection{Gerçeğe Uygun Değeri Üzerinden Ölçülen Finansal Varlıklar}

UFRS 9 Finansal Araçlar standardı uyarınca bir finansal varlık sözleşmeye bağlı nakit akışlarının tahsil edilmesini ve finansal varlığın satılmasını amaçlayan bir iş modeli kapsamında elde tutulması ve finansal varlığa ilişkin sözleşme şartlarının, belirli tarihlerde sadece anapara ve anapara bakiyesinden kaynaklanan faiz ödemelerini içeren nakit akışlarına yol açması halinde gerçeğe uygun değer değişimi diğer kapsamlı gelire yansıtılan finansal varlık olarak sinıflandırılır (UFRS 9, p. 4.1.2A). Ayrıca bir finansal varlık itfa edilmiş maliyeti üzerinden ya da gerçeğe uygun değer değişimi diğer kapsamlı gelire yansıtılarak ölçülmüyorsa, gerçeğe uygun değer değişimi kar veya zarara yansitılarak ölçülür (UFRS 9, p. 4.1.4). Standardın bu ifadesinden anlaşlacağı üzere gerçeğe uygun değer değişimi kar veya zarara yansıtılan finansal varlık sınıfı bir nevi "artık/geriye kalanlar/diğerleri" sınıfı olarak değerlendirilebilir. Bu çalışmanın konusu olan hisse senedi gibi özkaynak yatırımları, gerçeğe uygun değeri üzerinden ölçülen finansal varlıklar sınıfına girmektedir. 
Gerçeğe uygun değeri üzerinden ölçülen finansal varlıkların değer değişimlerinin diğer kapsamlı gelire mi yoksa kar veya zarara mı yansıtılması gerektiği işletmece karar verilmesi gereken önemli bir konudur. Bahsi geçen karara ilişkin aşağıdaki akış şeması kullanılabilir:

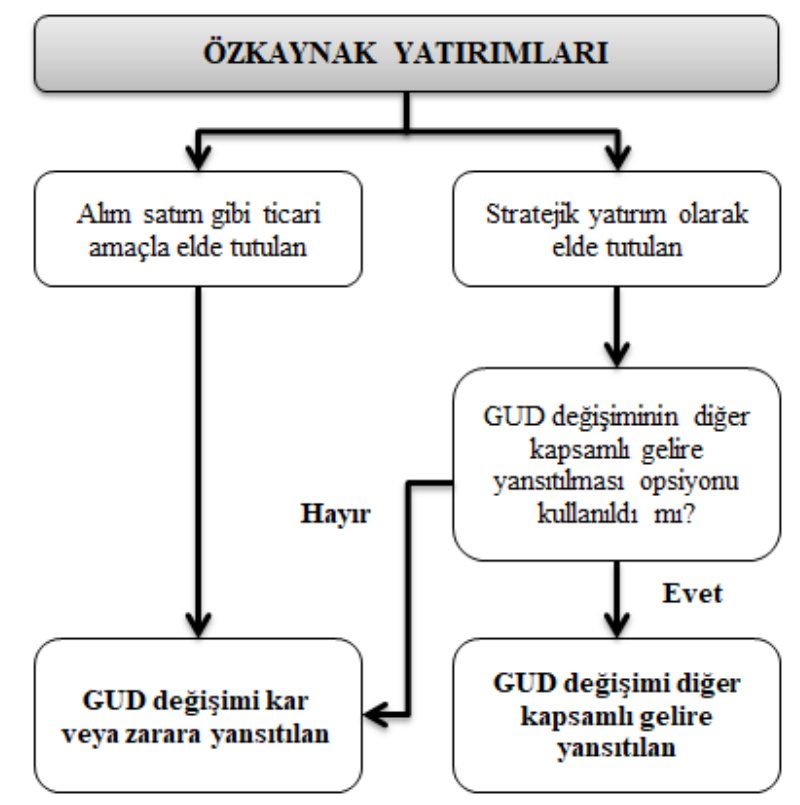

Şekil 1. Özkaynak Yatırımlarının Sınıflandırılması

\section{2. Ölçme}

\subsection{1. İlk Muhasebeleştirilme}

UFRS 9 Finansal Araçlar standardı uyarınca bir finansal varlık ilk defa finansal tablolara alınırken gerçeğe uygun değerden ölçülür. Gerçeğe uygun değer değişimleri kar veya zarara yansıtılanlar dışındaki finansal varlıkların ilk ölçümünde, ilgili varlıkların edinimiyle doğrudan ilişkilendirilebilen işlem maliyetleri de gerçeğe uygun değere ilave edilir. Burada ticari alacaklara ilişkin özel bir durum bulunmaktadır. Ticari alacakların UFRS 15 Müşteri Sözleşmelerinden Hasılat (IFRS 15 Revenue from Contract with Customers) standardı uyarınca önemli bir finansman bileşenine sahip olmaması veya işletmenin UFRS 15'in 63'üncü paragrafina göre kolaylaştırıcı uygulamayı seçmesi durumunda, bu alacaklar ilk defa finansal tablolara alınması sırasında UFRS $15^{\prime}$ te tanımlandığ şekliyle işlem bedeli üzerinden ölçülür (UFRS 9, p. 5.1.1-5.1.3). Gerçeğe uygun değer, ölçüm tarihinde piyasa katılımcıları arasında gerçekleşecek olağan bir işlemde bir varlığın satışından elde edilecek veya bir borcun devri nedeniyle ödenecek bedel olarak tanımlanmaktadır (UFRS 13, p. Ek A).

Bir finansal aracın ilk muhasebeleştirilmesinde gerçeğe uygun değeri normal işlem fiyatıdır. İlk muhasebeleştirmede gerçeğe uygun değerin işlem fiyatından farklı olduğunun belirlenmesi durumunda, söz konusu araç işlem tarihinde aşağıda belirtilen şekilde muhasebeleştirir (UFRS 9, p. B5.1.2A): 
Gerçeğe uygun değerin, özdeş bir varlığın veya yükümlülüğün aktif bir piyasadaki kotasyon fiyatıyla (diğer bir ifadeyle Seviye 1 girdisi) doğrulanması veya sadece gözlemlenebilir piyasalardan veriler kullanan bir değerleme yöntemine dayanması durumunda önceki paragrafta belirtilen ölçüm üzerinden. İşletme ilk defa finansal tablolara alma sırasındaki gerçeğe uygun değer ile işlem fiyatı arasındaki farkı kazanç veya kayıp olarak finansal tablolara alır.

Diğer tüm durumlarda, önceki paragrafta belirtilen ölçümün, ilk muhasebeleştirme sırasındaki gerçeğe uygun değer ile işlem fiyatı arasındaki farkın ertelenmesi amaciyla düzeltilmesi sonucunda bulunan tutar üzerinden. İşletme ilk defa finansal tablolara almasından sonra ertelenen bu farkı, piyasa katılımcılarının varlık veya yükümlülügü fiyatlandırırken göz önünde bulunduracakları bir faktördeki (zaman faktörü dahil) değişiklikten kaynaklandığı ölçüde kazanç veya kayıp olarak finansal tablolara alır.

\subsubsection{Sonraki Ölçüm}

UFRS 9 Finansal Araçlar standardı uyarınca finansal varlıkların üç kategoride ele alındığı çalışmanın önceki bölümünde belirtilmiştir. Finansal varlıkların raporlama tarihlerindeki değer değişimlerinin finansal tablolara olan etkisi ilgili finansal varlığın hangi kategoriye mensup olduğu ile ilgilidir. Aşağıdaki tabloda UMS 39 ve UFRS 9'un finansal varlıklar temelinden bir karşılaştırması verilmiştir:

Tablo 1. UMS 39 ile UFRS 9’un Finansal Varlıklar Açısından Karşılaştırılması

\begin{tabular}{|c|c|}
\hline UMS 39 & UFRS 9 \\
\hline \multicolumn{2}{|c|}{ Sinıflandırma } \\
\hline $\begin{array}{l}\text { - Satılmaya hazır finansal varlıklar } \\
\text { - Gerçeğe uygun değer değişimi kar veya zarara yansıtılan } \\
\text { finansal varlıklar } \\
\text { - Vadeye kadar elde tutulacak finansal varlıklar } \\
\text { - Kredi ve alacaklar }\end{array}$ & $\begin{array}{l}\text { - Gerçeğe uygun değer değişimi diğer kapsamlı gelire } \\
\text { yansıtılan finansal varlıklar } \\
\text { - Gerçeğe uygun değer değişimi kar veya zarara yansıtılan } \\
\text { finansal varlıklar } \\
\text { - İtfa edilmiş maliyeti üzerinden ölçülen finansal varlıklar }\end{array}$ \\
\hline \multicolumn{2}{|c|}{ İlk Muhasebeleştirme } \\
\hline - Gerçeğe uygun değer ile muhasebeleştirilir & - Gerçeğe uygun değer ile muhasebeleştirilir \\
\hline \multicolumn{2}{|c|}{ Sonraki Ölçüm } \\
\hline $\begin{array}{l}\text { - Satılmaya hazır finansal varlıklar gerçeğe uygun değerleri ile } \\
\text { ölçülür. Değerleme farkları kapsamlı gelir tablosundan } \\
\text { geçirilerek özkaynaklarda yeniden değerleme ve sınıflandırma } \\
\text { kazançları / (kayıpları) hesabına yansıtılır } \\
\text { - Gerçeğe uygun değer değişimi kar veya zarara yansıtılan } \\
\text { finansal varlıklar gerçeğe uygun değerleri ile ölçülür. Değerleme } \\
\text { farkları kar veya zarar tablosuna yansıtılır } \\
\text { - Vadeye kadar elde tutulacak finansal varlıklar itfa edilmiş } \\
\text { maliyetlerinden ölçülür. Değerleme farkları kar veya zarar } \\
\text { tablosuna yansıtılır } \\
\text { - Kredi ve alacaklar itfa edilmiş maliyetlerinden ölçülür. } \\
\text { Değerleme farkları kar veya zarar tablosuna yansıtılır }\end{array}$ & $\begin{array}{l}\text { - Gerçeğe uygun değer değişimi diğer kapsamlı gelire } \\
\text { yansıtılan finansal varlıklar gerçeğe uygun değerleri ile } \\
\text { ölçülür. Değerleme farkları kapsamlı gelir tablosundan } \\
\text { geçirilerek özkaynaklarda yeniden değerleme ve } \\
\text { sınıflandırma kazançları / (kayıpları) hesabına yansıtılır } \\
\text { - Gerçeğe uygun değer değişimi kar veya zarara yansıtılan } \\
\text { finansal varlıklar gerçeğe uygun değerleri ile ölçülür. } \\
\text { Değerleme farkları kar veya zarar tablosuna yansıtılır } \\
\text { - İtfa edilmiş maliyetinden ölçülen finansal varlıklar itfa } \\
\text { edilmiş maliyetlerinden ölçülür. Değerleme farkları kar veya } \\
\text { zarar tablosuna yansıtılır }\end{array}$ \\
\hline
\end{tabular}

Kaynak: Özulucan vd., 2017: 246 


\section{STANDARDIN İLK DEFA UYGULANIŞI}

Çalışmanın önceki bölümlerinde belirtildiği üzere UFRS 9 Finansal Araçlar standardı 1 Ocak 2018 tarihinde ve sonrasında başlayan hesap dönemlerine uygulanmak üzere UMS 39 Finansal Araçlar: Muhasebeleştirme ve Ölçme standardının yerini almıştır. UMS 39 uyarınca aktif bir piyasada kayıtlı bir fiyatı bulunmayan ve gerçeğe uygun değeri güvenilir bir şekilde ölçülemeyen hisse senedi yatırımlarının finansal tablolarda maliyet bedellerinden gösterilmesi mümkündür (UMS 39, p. 46). UFRS 9 uyarınca aktif bir piyasada özdeş bir finansal araç için kotasyon fiyatı olmayan özkaynak araçlarına yapılan yatırımın geçmişte UMS 39 uyarınca maliyet değeri üzerinden muhasebeleştirilmiş olması durumunda, bu finansal araç ilk uygulama tarihindeki gerçeğe uygun değeri üzerinden ölçülür. Daha önceki defter değeri ile gerçeğe uygun değeri arasındaki fark, ilk uygulama tarihini içeren raporlama dönemine iliş̧in dağıtılmamış karların (ya da uygun olması durumunda, diğer bir özkaynak bileşeninin) açııış bakiyesine yansıtılır (UFRS 9, p. 7.2.12). Ancak standart, bazı istisnai durumlarda, gerçeğe uygun değerin ölçümüne ilişkin yeterli düzeyde yakın zamanlı bilgi bulunmaması veya gerçeğe uygun değerin birden fazla yöntemle ölçülebilmesi ve bu yöntemler arasında maliyet bedelinin gerçeğe uygun değer tahminini en iyi şekilde yansitıyor olması halinde maliyet bedelinin gerçeğe uygun değerin belirlenmesine ilişkin uygun bir tahmin yöntemi olabileceğini belirtmektedir. Maliyet bedelinin gerçeğe uygun değeri yansttmayabileceği durumlara ilişkin göstergeler aşağıdaki gibidir (UFRS 9, p. B5.2.4):

a) Bütçeler, planlar veya önemli gelişmeler ile karşılaştırıldığında yatırım yapılan işletmenin performansında önemli bir değişiklik olması.

b) Yatırım yapılan işletmenin teknik bir ürüne ilişkin hedeflerine ulaşılacağı yönündeki beklentilerin değişmesi.

c) Yatırım yapılan işletmenin özkaynağına, ürünlerine veya muhtemel ürünlerine ilişkin piyasada önemli bir değişiklik olması.

d) Küresel ekonomide veya yatırım yapılan işletmenin faaliyet gösterdiği ekonomik çevrede önemli bir değişiklik olması.

e) Karşılaştırılabilir işletmelerin performansında veya piyasa genelinde ortaya konan değerlemelerde önemli bir değişiklik olması.

f) Yatırım yapılan işletmenin, hile, ticari anlaşmazlıklar, ihtilaf, işletme yönetiminde veya stratejisinde meydana gelen değişiklikler gibi içsel sorunlarının bulunması.

g) Yatırım yapılan işletmenin özkaynaklarıyla ilgili olarak, doğrudan söz konusu işletme tarafindan yapılan (yeni bir pay ihracı gibi) veya üçüncü kişiler arasında gerçekleştirilen işlemlerden elde edilen kanttlar.

$\mathrm{Bu}$ göstergeler incelendiğinde, pratikte, maliyet bedelinin gerçeğe uygun değeri yansıtmasının pek mümkün olmadığı söylenebilecektir. Başka bir deyişle standart uyarınca işletmelerin aktifinde bulunan tüm özkaynak yatırımlarının gerçeğe uygun değerlerinin ölçülmesi gerekmektedir. 


\section{UYGULAMA}

Çalışmanın bu bölümünde UFRS 9 uyarınca özkaynak yatırımlarının muhasebeleştirilmesine ilişkin örnek bir uygulama gerçekleştirilecektir.

Aşağıda bir A işletmesinin 2017 ve raporlama yılı olan 2018 yılına ilişkin UMS 39 hükümlerine göre hazırlanmış finansal tabloları verilmiştir: ${ }^{1}$

Tablo 2. A İşletmesi Karşılaştırmalı Bilançoları (UMS 39)

\begin{tabular}{|c|c|c|}
\hline \multicolumn{3}{|l|}{ A İŞLETMESİ BILLANÇO } \\
\hline VARLIKLAR & 31 Aralık 2017 & 31 Aralık 2018 \\
\hline Dönen Varlıklar & 6.324.000 & 7.017.000 \\
\hline Nakit ve nakit benzerleri & 2.986 .000 & 3.314 .000 \\
\hline Ticari alacaklar & 1.890 .000 & 2.098 .000 \\
\hline Stoklar & 1.126 .000 & 1.250 .000 \\
\hline Cari dönem vergisi ile ilgili varlıklar & 66.000 & 71.000 \\
\hline Diğer dönen varlıklar & 256.000 & 284.000 \\
\hline Duran Varlıklar & 1.962 .500 & 2.174.000 \\
\hline Finansal yatırımlar & 156.500 & 170.000 \\
\hline Ticari alacaklar & 77.000 & 85.000 \\
\hline Maddi duran varlıklar & 1.597 .000 & 1.773 .000 \\
\hline Maddi olmayan duran varlıklar & 22.000 & 24.000 \\
\hline Ertelenmiş vergi varlı̆̆g & 16.000 & 18.000 \\
\hline Diğer duran varlıklar & 94.000 & 104.000 \\
\hline TOPLAM VARLIKLAR & 8.286 .500 & 9.191 .000 \\
\hline KAYNAKLAR & 31 Aralık 2017 & 31 Aralık 2018 \\
\hline Kısa Vadeli Yükümlülükler & 4.295.250 & 4.107.475 \\
\hline Kısa vadeli borçlanmalar & 1.923 .450 & 2.124 .875 \\
\hline Ticari borçlar & 2.042 .000 & 1.607 .000 \\
\hline Dönem karı vergi yükümlülüğüü & 151.800 & 177.600 \\
\hline Kısa vadeli karşılıklar & 178.000 & 198.000 \\
\hline Uzun Vadeli Yükümlülükler & 751.000 & 833.000 \\
\hline Uzun vadeli borçlanmalar & 576.000 & 639.000 \\
\hline Ticari borçlar & 117.000 & 130.000 \\
\hline Uzun vadeli karşılıklar & 58.000 & 64.000 \\
\hline Özkaynaklar & 3.240 .250 & 4.250.525 \\
\hline Ödenmiş sermaye & 674.000 & 674.000 \\
\hline $\begin{array}{l}\text { Kar veya zararda yeniden sınıflandırılmayacak birikmiş diğer kapsamlı } \\
\text { gelirler (giderler) }\end{array}$ & $(2.000)$ & 4.000 \\
\hline - Yeniden değerleme ve ölçüm kazançları (kayıpları) & $(2.000)$ & 4.000 \\
\hline $\begin{array}{l}\text { Kar veya zararda yeniden sınıflandırılacak birikmiş diğer kapsamlı gelirler } \\
\text { (giderler) }\end{array}$ & 52.250 & 64.125 \\
\hline - Yeniden değerleme ve sinıflandırma kazançları & 52.250 & 64.125 \\
\hline Kardan ayrılan kısıtlanmış yedekler & 200.000 & 220.000 \\
\hline Geçmiş yıllar karları & 1.452 .800 & 2.296 .000 \\
\hline Net dönem karı & 863.200 & 992.400 \\
\hline TOPLAM KAYNAKLAR & 8.286 .500 & 9.191 .000 \\
\hline
\end{tabular}

\footnotetext{
${ }^{1}$ Uygulamada sadece özkaynak yatırımları incelenecek olup diğer finansal varlık / kaynakların UFRS 9 düzeltmeleri göz ardı edilecektir.
} 
Tablo 3. A İşletmesi Karşılaş̧ırmalı Kar veya Zarar ve Diğer Kapsamlı Gelir Tabloları (UMS 39)

\begin{tabular}{|c|c|c|}
\hline $\begin{array}{l}\text { A İŞLETMESI KAR VEYA ZARAR VE DİĞER KAPSAMLI } \\
\text { GELIR TABLOSU }\end{array}$ & $\begin{array}{r}1 \text { Ocak - } \\
31 \text { Aralık } 2017\end{array}$ & $\begin{array}{r}1 \text { Ocak - } \\
31 \text { Aralık } 2018\end{array}$ \\
\hline Hasılat & 7.885 .000 & 8.672 .000 \\
\hline Satışların maliyeti (-) & $(6.459 .000)$ & $(7.105 .000)$ \\
\hline BRÜT KAR & 1.426 .000 & 1.567 .000 \\
\hline Genel yönetim giderleri (-) & $(215.000)$ & $(237.000)$ \\
\hline Pazarlama giderleri (-) & $(155.000)$ & $(171.000)$ \\
\hline Araştırma ve geliştirme giderleri (-) & $(2.000)$ & $(2.000)$ \\
\hline Esas faaliyetlerden diğer gelirler & 340.000 & 374.000 \\
\hline Esas faaliyetlerden diğer giderler (-) & $(429.000)$ & $(472.000)$ \\
\hline ESAS FAALIYET KARI & 965.000 & 1.059 .000 \\
\hline Yatırım faaliyetlerinden gelirler & 65.000 & 88.000 \\
\hline Yatırım faaliyetlerinden giderler (-) & $(48.000)$ & $(22.000)$ \\
\hline FİNANSMAN GELİII (GIDERI) ÖNCESİ FAALIYET KARI & 982.000 & 1.125 .000 \\
\hline Finansman gelirleri & 576.000 & 634.000 \\
\hline Finansman giderleri (-) & $(469.000)$ & $(516.000)$ \\
\hline SÜRDÜRÜLEN FAALIYETLER VERGİ ÖNCESI KARI & 1.089 .000 & 1.243.000 \\
\hline Sürdürülen Faaliyetler Vergi Gideri (-) & $(225.800)$ & $(250.600)$ \\
\hline Dönem vergi gideri (-) & $(217.800)$ & $(248.600)$ \\
\hline Ertelenmiş vergi (gideri) geliri & $(8.000)$ & $(2.000)$ \\
\hline SÜRDÜRÜLEN FAALIYETLER DÖNEM KARI & 863.200 & 992.400 \\
\hline \multicolumn{3}{|l|}{ DİĞER KAPSAMLI GELİRLER } \\
\hline Kar veya zararda yeniden sinıflandırılmayacaklar & (3.200) & 6.000 \\
\hline Tanımlanmış fayda planları yeniden ölçüm kazançları (kayıpları) & $(4.000)$ & 7.500 \\
\hline $\begin{array}{l}\text { Kar veya zararda yeniden sınıflandırılmayacak diğer kapsamlı gelire } \\
\text { ilişkin vergiler }\end{array}$ & 800 & $(1.500)$ \\
\hline - Ertelenmiş vergi (gideri) geliri & 800 & $(1.500)$ \\
\hline Kar veya zarar olarak yeniden sınıflandırılacaklar & 12.350 & 11.875 \\
\hline Finansal varlıkların yeniden değerleme kazançları & 13.000 & 12.500 \\
\hline $\begin{array}{l}\text { Kar veya zararda yeniden sınıflandırılacak diğer kapsamlı gelire ilişkin } \\
\text { vergiler }\end{array}$ & $(650)$ & $(625)$ \\
\hline - Ertelenmiş vergi gideri (-) & $(650)$ & $(625)$ \\
\hline DİĞER KAPSAMLI GELİR & 9.150 & 17.875 \\
\hline TOPLAM KAPSAMLI GELİR & 872.350 & 1.010 .275 \\
\hline
\end{tabular}


Tablo 4. A İşletmesi Karşılaştırmalı Özkaynaklar Değişim Tabloları (UMS 39)

\begin{tabular}{|c|c|c|c|c|c|c|c|}
\hline $\begin{array}{l}\text { A İŞLETMESİ ÖZKAYNAKLAR DEĞİŞIM } \\
\text { TABLOSU }\end{array}$ & $\begin{array}{l}\text { Ödenmiş } \\
\text { Sermaye }\end{array}$ & $\begin{array}{r}\text { Yeniden } \\
\text { Değerleme } \\
\text { ve Ölçüm } \\
\text { Kazançları } \\
\text { (Kayıpları) }\end{array}$ & $\begin{array}{r}\text { Yeniden } \\
\text { Değerleme ve } \\
\text { Sinıflandırma } \\
\text { Kazançları }\end{array}$ & $\begin{array}{r}\text { Kardan } \\
\text { Ayrılan } \\
\text { Kısıtlanmış } \\
\text { Yedekler }\end{array}$ & $\begin{array}{r}\text { Geçmiş } \\
\text { Yıllar } \\
\text { Karları }\end{array}$ & $\begin{array}{r}\text { Net Dönem } \\
\text { Karı }\end{array}$ & $\begin{array}{r}\text { Toplam } \\
\text { Özkaynaklar }\end{array}$ \\
\hline 1 Ocak 2017 itibarıyla açılış bakiyesi & 674.000 & 1.200 & 39.900 & 180.000 & 936.000 & 536.800 & 2.367 .900 \\
\hline Transferler & - & - & - & 20.000 & 516.800 & $(536.800)$ & \\
\hline Toplam kapsamlı gelir (gider) & - & (3.200) & 12.350 & - & - & 863.200 & 872.350 \\
\hline - Dönem karl & - & - & - & - & - & 863.200 & 863.200 \\
\hline - Diğer kapsamlı gelir (gider) & - & $(3.200)$ & 12.350 & - & - & & 9.150 \\
\hline 31 Aralık 2017 itibarıyla kapanış bakiyesi & 674.000 & (2.000) & 52.250 & 200.000 & 1.452 .800 & 863.200 & 3.240 .250 \\
\hline 1 Ocak 2018 itibarıyla açılış bakiyesi & 674.000 & $(2.000)$ & 52.250 & 200.000 & 1.452.800 & 863.200 & 3.240 .250 \\
\hline Transferler & - & - & - & 20.000 & 843.200 & $(863.200)$ & - \\
\hline Toplam kapsamlı gelir & - & 6.000 & 11.875 & - & - & 992.400 & 1.010 .275 \\
\hline - Dönem karl & - & - & - & - & - & 992.400 & 992.400 \\
\hline - Diğer kapsamlı gelir & - & 6.000 & 11.875 & - & - & - & 17.875 \\
\hline 31 Aralık 2018 itibarıyla kapanış bakiyesi & 674.000 & 4.000 & 64.125 & 220.000 & 2.296 .000 & 992.400 & 4.250 .525 \\
\hline
\end{tabular}

A işletmesinin aktifleri arasında hisse senedi yatırımları bulunmakta olup bilançoda finansal yatırımlar arasında gösterilmektedir. Söz konusu hisse senedi yatırımlarına ilişkin detaylar aşağıdaki gibidir:

Tablo 5. A İşletmesi Finansal Yatırımlar Detayı

\begin{tabular}{|c|c|c|c|c|c|c|c|}
\hline Finansal Varlıklar & Borsa Kotasyonu & Katılım Oranı & Maliyet Bedeli & UMS 39 Sinıflandırma & UMS 39 Değeri & UFRS 9 Sinıflandırma & UFRS 9 Değeri \\
\hline Finansal Yatırım 1 & Var & $\% 6$ & 19.000 & \multirow{5}{*}{ Satılmaya Hazır } & GUD & \multirow{5}{*}{$\begin{array}{l}\text { Gerçeğe Uygun Değer } \\
\text { Değişimi Diğer } \\
\text { Kapsamlı Gelire } \\
\text { Yansitılan }\end{array}$} & \multirow{5}{*}{ GUD } \\
\hline Finansal Yatırım 2 & Var & $\% 5$ & 26.000 & & GUD & & \\
\hline Finansal Yatırım 3 & Var & $\% 4$ & 32.000 & & GUD & & \\
\hline Finansal Yatırım 4 & Yok & $\% 2$ & 15.000 & & Maliyet Bedeli & & \\
\hline Finansal Yatırım 5 & Yok & $\% 1$ & 12.000 & & Maliyet Bedeli & & \\
\hline
\end{tabular}


Tablo incelendiğinde A işletmesinin hisse senedi yatırımlarının UMS 39 uyarınca satılmaya hazır finansal varlık olarak nitelendirildiği görülmektedir. 1,2 ve 3 numaralı yatırımların borsaya kote işletmeler olmasından ötürü gerçeğe uygun değerleri güvenilir şekilde ölçülebilmekte ve bu nedenle finansal tablolarda gerçeğe uygun değerlerinden gösterilmektedir. 4 ve 5 numaralı yatırımlar aktif bir piyasada kayıtlı bir fiyatı bulunmayan ve gerçeğe uygun değeri güvenilir bir şekilde ölçülemeyen hisse senedi yatırımları olup finansal tablolarda maliyet bedellerinden gösterilmektedir. A işletmesi finansal yatırımlarını mevcut iş modeli kapsamında gerçeğe uygun değer değişimi diğer kapsamlı gelire yansıtılan finansal varlık olarak nitelendirmektedir. $\mathrm{Bu}$ nedenle 4 ve 5 numaralı yatırımların gerçeğe uygun değerlerinin belirlenmesi gerekmektedir. 31 Aralık 2017 ve 31 Aralık 2018 tarihleri itibarıyla A işletmesinin hisse senedi yatırımlarının maliyet bedelleri, borsaya kote olan 1, 2 ve 3 numaralı yatırımların borsa rayiçleri ile 4 ve 5 numaralı yatırımların bir değerleme kuruluşunca yapılan çalışma neticesinde hesaplanan gerçeğe uygun değerleri aşağıdaki gibidir:

Tablo 6. A İşletmesi Finansal Yatırımlar Ölçümü

\begin{tabular}{|l|c|c|c|}
\hline Finansal Varlıklar & Maliyet Bedeli & \multicolumn{2}{|c|}{ Gerçeğe Uygun Değer } \\
\hline Finansal Yatırım 1 & 19.000 & 16.500 & 17.500 \\
\hline Finansal Yatırım 2 & 26.000 & 46.000 & 56.000 \\
\hline Finansal Yatırım 3 & 32.000 & 67.000 & 69.500 \\
\hline Finansal Yatırım 4 & 15.000 & 20.000 & 22.000 \\
\hline Finansal Yatırım 5 & 12.000 & 10.000 & 15.000 \\
\hline
\end{tabular}

Çalışmanın önceki bölümünde geçmişte UMS 39 uyarınca maliyet değeri üzerinden muhasebeleştirilmiş özkaynak araçlarına yapılan yatırımların UFRS 9 uyarınca ilk uygulama tarihindeki gerçeğe uygun değeri üzerinden ölçüleceği ve daha önceki defter değeri ile gerçeğe uygun değeri arasındaki farkın ilk uygulama tarihini içeren raporlama dönemine ilişkin dağıtılmamış karların (ya da uygun olması durumunda, diğer bir özkaynak bileşeninin) açılış bakiyesine yansıtılacağı belirtilmiştir. Buna göre daha önce UMS 39 uyarınca maliyet bedelleriyle finansal tablolarda raporlanan 4 ve 5 numaralı yatırımların 31 Aralık 2017 tarihindeki kapanış (başka bir deyişle 1 Ocak 2018 tarihindeki açılış) gerçeğe uygun değer farkları bir özkaynak bileşeninde gösterilecek ve böylece 31 Aralık 2017 tarihli finansal tabloların yeniden düzenlenmesine gerek kalmayacaktır. Ayrıca 1 numaralı finansal yatırımın gerek 31 Aralık 2017'de ve gerekse de 31 Aralık 2018'de değer düşüklüğüne uğradığ 1 görülmektedir. UMS 39 uyarınca satılmaya hazır finansal varlıklardaki değer düşüklükleri gelir tablosunda muhasebeleştirilmektedir. Ancak A işletmesinin finansal yatırımlarını gerçeğe uygun değer değişimi diğer kapsamlı gelire yansıtılan finansal varlık olarak sınıflandırmasından ötürü ilgili finansal varlığa ilişkin geçmiş dönem etkilerinin de sınıflandırılması gerekecektir. Buna göre 1, 4 ve 5 numaralı finansal yatırımlara ilişkin açılış düzeltmesi aşağıdaki gibi olacaktır: 


\begin{tabular}{|l|l|r|r|}
\hline \multicolumn{1}{|c|}{ Finansal Tablo } & \multicolumn{1}{|c}{ Hesap } & Borç & Alacak \\
\hline Bilanço & Yeniden değerleme ve sınıflandırma kazançları & 2.375 & \\
\hline Bilanço & Geçmiş yıllar karları & 2.375 \\
\hline Bilanço & Finansal yatırımlar & 3.000 & \\
\hline Bilanço & Yeniden değerleme ve sınıflandırma kazançları & 2.850 \\
\hline Bilanço & Ertelenmiş vergi yükümlülüğü & 150 \\
\hline
\end{tabular}

1 numaralı finansal yatırımın defter değeri (19.000 TL) ile gerçeğe uygun değeri (16.500 TL) arasındaki 2.500 TL'lik farktan $\% 5^{2}$ oranındaki ertelenmiş vergi etkisinin (125 TL) indirilmesiyle 2.375 TL'lik 31 Aralık 2017 kapanış (başka bir deyişle 1 Ocak 2018 açılış) anındaki kümüle değerleme farkı hesaplanmaktadır. 1 numaralı finansal yatırımın gerçeğe uygun değer değişimi diğer kapsamlı gelire yansıtılan finansal varlık olarak sınıflandırmasından ötürü ilgili tutar geçmiş yıllar karları hesabından özkaynak bileşeni olan yeniden değerleme ve sınıflandırma kazançları hesabına sınıflandırılmıştır. Ayrıca 4 ve 5 numaralı finansal yatırımlara ilişkin olarak 150 TL'lik ertelenmiş vergi etkisi düşülmüş net 2.850 TL'lik değerleme farkı $(20.000+10.000-15.000-12.000=$ 3.000) da yeniden değerleme ve sınıflandırma kazançları hesabına açılış düzeltmesi olarak yansitılmıştır.

Raporlama tarihi olan 31 Aralık 2018'de ise aşağıdaki kayıt gerçekleştirilecektir:

\begin{tabular}{|c|c|c|c|}
\hline Finansal Tablo & Hesap & Borç & Alacak \\
\hline Gelir Tablosu & Yatırım faaliyetlerinden gelirler & 1.000 & \\
\hline Kapsamlı Gelir Tablosu & Finansal yatırımların yeniden değerleme kazançları & & 1.000 \\
\hline Kapsamlı Gelir Tablosu & $\begin{array}{l}\text { Kar veya zararda yeniden sınıflandırılacak diğer } \\
\text { kapsamlı gelire ilişkin vergiler }\end{array}$ & 50 & \\
\hline Gelir Tablosu & Ertelenmiş vergi gideri & & 50 \\
\hline Bilanço & Finansal yatırımlar & 7.000 & \\
\hline Kapsamlı Gelir Tablosu & Finansal yatırımların yeniden değerleme kazançları & & 7.000 \\
\hline Kapsamlı Gelir Tablosu & $\begin{array}{l}\text { Kar veya zararda yeniden sınıflandırılacak diğer } \\
\text { kapsamlı gelire ilişkin vergiler }\end{array}$ & 350 & \\
\hline Bilanço & Ertelenmiş vergi yükümlülüğü & & 350 \\
\hline
\end{tabular}

2018 y1lı içerisinde 1 numaralı finansal yatırımın gerçeğe uygun değerindeki 1.000 TL'lik pozitif $(17.500-16.500=1.000 \mathrm{TL})$ değişim ve bu değişime ilişkin 50 TL'lik ertelenmiş vergi etkisi UMS 39 uyarınca yatırım faaliyetlerinden gelirler kalemi kullanılarak gelir tablosuna yansıtılmıştır. Yukarıdaki kayıt ile bu tutarlar yatırım faaliyetlerinden gelirler ve ertelenmiş vergi giderinden kapsamlı gelir unsuru olan finansal yatırımların yeniden değerleme kazançları ile kar veya zararda yeniden sınıflandırılacak diğer kapsamlı gelire ilişkin vergiler hesaplarına sınıflandırılmıştır. Ayrıca 4 ve 5 numaralı finansal yatırımlara ilişkin 7.000 TL'lik değerleme farkı ve bu farka ilişkin 350 TL'lik ertelenmiş vergi gideri kapsamlı gelir tablosunda muhasebeleştirilmiştir. Kapsamlı gelir unsurları bilançoda özkaynak bileşeni olan yeniden değerleme ve sınıflandırma kazançları hesabına yansımaktadır. Bu kayıtların

\footnotetext{
${ }^{2}$ Çalışmada genel vergi oranı \%20 olarak kabul edilmiştir. Hisse senedi yatırımlarının gelecekte satılması halinde elde edilecek kazancın \%75'i vergiden istisnadır. Bu nedenle ilgili kazancın vergiye tabi $\% 25^{\prime}$ lik kısmı üzerinden \%20 vergi hesaplanmıştır.
} 
etkisi sonrası A işletmesinin 31 Aralık 2018 itibarıyla finansal tabloları aşağıdaki gibi olacaktır:

Tablo 7. UFRS 9 Uygulaması Sonrası A İşletmesi Bilançosu

\begin{tabular}{|c|c|c|c|}
\hline \multirow{2}{*}{$\begin{array}{l}\text { A İŞLETMESİ BİLANÇO } \\
\text { VARLIKLAR }\end{array}$} & \multicolumn{3}{|c|}{31 Aralık 2018} \\
\hline & UMS 39 & UFRS 9 & FARK \\
\hline Dönen Varlıklar & 7.017.000 & 7.017.000 & - \\
\hline Nakit ve nakit benzerleri & 3.314 .000 & 3.314 .000 & - \\
\hline Ticari alacaklar & 2.098 .000 & 2.098 .000 & - \\
\hline Stoklar & 1.250 .000 & 1.250 .000 & - \\
\hline Cari dönem vergisi ile ilgili varlıklar & 71.000 & 71.000 & - \\
\hline Diğer dönen varlıklar & 284.000 & 284.000 & - \\
\hline Duran Varlıklar & 2.174.000 & 2.184.000 & 10.000 \\
\hline Finansal yatırımlar & 170.000 & 180.000 & 10.000 \\
\hline Ticari alacaklar & 85.000 & 85.000 & - \\
\hline Maddi duran varlıklar & 1.773 .000 & 1.773 .000 & - \\
\hline Maddi olmayan duran varlıklar & 24.000 & 24.000 & - \\
\hline Ertelenmiş vergi varlığı & 18.000 & 18.000 & - \\
\hline Diğer duran varlıklar & 104.000 & 104.000 & - \\
\hline TOPLAM VARLIKLAR & 9.191.000 & 9.201 .000 & 10.000 \\
\hline KAYNAKLAR & UMS 39 & UFRS 9 & FARK \\
\hline Kısa Vadeli Yükümlülükler & 4.107.475 & 4.107.475 & - \\
\hline Kısa vadeli borçlanmalar & 2.124.875 & 2.124.875 & - \\
\hline Ticari borçlar & 1.607 .000 & 1.607 .000 & - \\
\hline Dönem karı vergi yükümlülüğg̈ & 177.600 & 177.600 & - \\
\hline Kısa vadeli karş1lıklar & 198.000 & 198.000 & - \\
\hline Uzun Vadeli Yükümlülükler & 833.000 & 833.500 & 500 \\
\hline Uzun vadeli borçlanmalar & 639.000 & 639.000 & - \\
\hline Ticari borçlar & 130.000 & 130.000 & - \\
\hline Uzun vadeli karşıllılar & 64.000 & 64.000 & - \\
\hline Ertelenmiş vergi yükümlülüğü & - & 500 & 500 \\
\hline Özkaynaklar & 4.250 .525 & 4.260 .025 & 9.500 \\
\hline Ödenmiş sermaye & 674.000 & 674.000 & - \\
\hline $\begin{array}{l}\text { Kar veya zararda yeniden sinıflandırılmayacak } \\
\text { birikmiş diğer kapsamlı gelirler (giderler) }\end{array}$ & 4.000 & 4.000 & - \\
\hline - Yeniden değerleme ve ölçüm kazançları (kayıpları) & 4.000 & 4.000 & - \\
\hline $\begin{array}{l}\text { Kar veya zararda yeniden sinıflandırılacak } \\
\text { birikmiş diğer kapsamlı gelirler (giderler) }\end{array}$ & 64.125 & 72.200 & 8.075 \\
\hline - Yeniden değerleme ve sinıflandirma kazançları & 64.125 & 72.200 & 8.075 \\
\hline Kardan ayrılan kısıtlanmış yedekler & 220.000 & 220.000 & \\
\hline Geçmiş yıllar karları & 2.296 .000 & 2.298 .375 & 2.375 \\
\hline Net dönem karı & 992.400 & 991.450 & $(950)$ \\
\hline TOPLAM KAYNAKLAR & 9.191.000 & 9.201 .000 & 10.000 \\
\hline
\end{tabular}


Tablo 8. UFRS 9 Uygulaması Sonrası A İşletmesi Kar veya Zarar ve Diğer Kapsamlı Gelir Tablosu

\begin{tabular}{|c|c|c|c|}
\hline \multirow{2}{*}{$\begin{array}{l}\text { A İŞLETMESI KAR VEYA ZARAR VE DİĞER KAPSAMLI } \\
\text { GELIR TABLOSU }\end{array}$} & \multicolumn{3}{|c|}{1 Ocak - 31 Aralık 2018} \\
\hline & UMS 39 & UFRS 9 & FARK \\
\hline Hasilat & 8.672 .000 & 8.672 .000 & \\
\hline Satışların maliyeti (-) & $(7.105 .000)$ & $(7.105 .000)$ & \\
\hline BRÜT KAR & 1.567.000 & 1.567.000 & \\
\hline Genel yönetim giderleri (-) & $(237.000)$ & $(237.000)$ & \\
\hline Pazarlama giderleri (-) & $(171.000)$ & $(171.000)$ & \\
\hline Araştırma ve geliştirme giderleri (-) & $(2.000)$ & $(2.000)$ & \\
\hline Esas faaliyetlerden diğer gelirler & 374.000 & 374.000 & \\
\hline Esas faaliyetlerden diğer giderler (-) & (472.000) & $(472.000)$ & \\
\hline ESAS FAALIYYT KARI & 1.059 .000 & 1.059 .000 & \\
\hline Yatırım faaliyetlerinden gelirler & 88.000 & 87.000 & $(1.000)$ \\
\hline Yatırım faaliyetlerinden giderler (-) & $(22.000)$ & $(22.000)$ & \\
\hline FINANSMAN GELIRİ (GIDEERI) ÖNCESİ FAALIYET KARI & 1.125.000 & 1.124.000 & (1.000) \\
\hline Finansman gelirleri & 634.000 & 634.000 & \\
\hline Finansman giderleri (-) & $(516.000)$ & $(516.000)$ & \\
\hline SÜRDÜRÜLEN FAALIYETLER VERGİ ÖNCESİ KARI & 1.243.000 & 1.242 .000 & (1.000) \\
\hline Sürdürülen Faaliyetler Vergi Gideri (-) & $(250.600)$ & $(250.550)$ & $\mathbf{5 0}$ \\
\hline Dönem vergi gideri (-) & $(248.600)$ & $(248.600)$ & \\
\hline Ertelenmiş vergi (gideri) geliri & $(2.000)$ & (1.950) & 50 \\
\hline SÜRDÜRÜLEN FAALIYETLER DÖNEM KARI & 992.400 & 991.450 & (950) \\
\hline \multicolumn{4}{|l|}{ DİĞER KAPSAMLI GELİRLER } \\
\hline Kar veya zararda yeniden sınıflandırılmayacaklar & 6.000 & 6.000 & \\
\hline Tanımlanmış fayda planları yeniden ölçüm kazançları (kayıpları) & 7.500 & 7.500 & \\
\hline $\begin{array}{l}\text { Kar veya zararda yeniden sınıflandırılmayacak diğer kapsamlı } \\
\text { gelire ilişkin vergiler }\end{array}$ & $(1.500)$ & $(1.500)$ & \\
\hline - Ertelenmiş vergi (gideri) geliri & $(1.500)$ & $(1.500)$ & \\
\hline Kar veya zarar olarak yeniden sınıflandırılacaklar & 11.875 & 19.475 & 7.600 \\
\hline Finansal varlıkların yeniden değerleme kazançları & 12.500 & 20.500 & 8.000 \\
\hline $\begin{array}{l}\text { Kar veya zararda yeniden sınıflandırılacak diğer kapsamlı gelire } \\
\text { ilişkin vergiler }\end{array}$ & $(625)$ & $(1.025)$ & $(400)$ \\
\hline - Ertelenmiş vergi gideri (-) & $(625)$ & $(1.025)$ & $(400)$ \\
\hline DİĞER KAPSAMLI GELİR & 17.875 & 25.475 & 7.600 \\
\hline TOPLAM KAPSAMLI GELIIR & 1.010.275 & 1.016 .925 & 6.650 \\
\hline
\end{tabular}


$\begin{array}{ll}\text { The Journal of Accounting and Finance- July/2019 } & \text { (83): 131-146 }\end{array}$

Tablo 9. UFRS 9 Uygulaması Sonrası A İşletmesi Özkaynaklar Değişim Tablosu

\begin{tabular}{|c|c|c|c|c|c|c|c|}
\hline A İŞLETMESİ ÖZKAYNAKLAR DEĞİŞIM TABLOSU & $\begin{array}{l}\text { Ödenmiş } \\
\text { Sermaye }\end{array}$ & $\begin{array}{r}\text { Yeniden } \\
\text { Değerleme } \\
\text { ve Ölçüm } \\
\text { Kazançları } \\
\text { (Kayıpları) }\end{array}$ & $\begin{array}{r}\text { Yeniden } \\
\text { Değerleme ve } \\
\text { Sinıflandırma } \\
\text { Kazançları }\end{array}$ & $\begin{array}{r}\text { Kardan } \\
\text { Ayrılan } \\
\text { Kisıtlanmış } \\
\text { Yedekler }\end{array}$ & $\begin{array}{r}\text { Geçmiş } \\
\text { Yıllar } \\
\text { Karları }\end{array}$ & $\begin{array}{r}\text { Net Dönem } \\
\text { Karı }\end{array}$ & $\begin{array}{r}\text { Toplam } \\
\text { Özkaynaklar }\end{array}$ \\
\hline 1 Ocak 2018 itibarıyla açılış bakiyesi & 674.000 & $(2.000)$ & $\mathbf{5 2 . 2 5 0}$ & 200.000 & 1.452.800 & 863.200 & 3.240 .250 \\
\hline Muhasebe politikalarındaki değişikliklerin etkisi & - & - & 475 & - & 2.375 & - & 2.850 \\
\hline 1 Ocak 2018 itibarıyla yeniden düzenlenmiş açılış bakiyesi & 674.000 & $(2.000)$ & 52.725 & 200.000 & 1.455.175 & 863.200 & 3.243.100 \\
\hline Transferler & - & - & - & 20.000 & 843.200 & $(863.200)$ & \\
\hline Toplam kapsamlı gelir & - & 6.000 & 19.475 & - & - & 991.450 & 1.016.925 \\
\hline - Dönem karı & - & - & - & - & - & 991.450 & 991.450 \\
\hline - Diğer kapsamll gelir & - & 6.000 & 19.475 & - & - & - & 25.475 \\
\hline 31 Aralık 2018 itibarıyla kapanış bakiyesi (UFRS 9) & 674.000 & 4.000 & 72.200 & 220.000 & 2.298.375 & 991.450 & 4.260 .025 \\
\hline 31 Aralık 2018 itibarıyla kapanış bakiyesi (UMS 9) & 674.000 & 4.000 & 64.125 & 220.000 & 2.296 .000 & 992.400 & 4.250 .525 \\
\hline FARK & - & - & 8.075 & - & 2.375 & (950) & 9.500 \\
\hline
\end{tabular}


Yukarıda görüleceği üzere açılış kaydının etkisi özkaynaklar değişim tablosuna eklenen "Muhasebe politikalarındaki değişikliklerin etkisi" başlıklı yeni bir satırda gösterilmiştir $(2.850-2.375=475$ TL yeniden değerleme ve sınıflandırma kazançları; 2.375 TL geçmiş yıllar karları). 7.600 TL tutarlı cari dönem etkisi önceden raporlanmış diğer kapsamlı gelir satırındaki tutara eklenmiştir $(11.875+7.600=19.475)$.

\section{SONUÇ}

UFRS 9 Finansal Araçlar standardı 1 Ocak 2018 tarihinde ve sonrasında başlayan hesap dönemlerine uygulanmak üzere UMS 39 Finansal Araçlar: Muhasebeleştirme ve Ölçme standardının yerini almıştır. UMS 39 Finansal Araçlar: Muhasebeleştirme ve Ölçme standardı uyarınca özkaynak yatırımlarının maliyet bedeli ile izlenmesi mümkündür. Ancak UFRS 9 Finansal Araçlar standardı hükümlerine göre özkaynak yatırımlarının maliyet bedeli üzerinden ölçülebilmesi opsiyonu ortadan kalkmıştır. Başka bir deyişle işletmelerin aktiflerinde bulunan özkaynak yatırımlarının gerçeğe uygun değerlerini belirlemeleri ve hesaplanan bu değer üzerinden finansal tablolarına yansıtmaları gerekmektedir. Türkiye'de özellikle büyük grupların ana ortaklıklarının aktifinde çok sayıda özkaynak yatırımı bulunmaktadır. $\mathrm{Bu}$ yatırımlar içerisinde aktif bir piyasada kotasyon fiyatı bulunanların yanında herhangi bir piyasada işlem görmeyen yatırımlar da bulunmaktadır. Bu noktada söz konusu yatırımların gerçeğe uygun değerlerinin nasıl belirleneceği sorunsalı ortaya çıkmaktadır. Aşağıda bu sorunsala ilişkin iki senaryo verilmiştir:

Bir yatırımcı işletmenin aktifinde bulunan \%0,1 katılım oranlı bir yatırımının gerçeğe uygun değeri nasıl hesaplanacaktır? (Yatırımın defter değeri yatırımcının finansal tablolarında önemli düzeyde değildir),

Bir yatırımcı işletmenin aktifinde bulunan ve UMS 39 Finansal Araçlar: Muhasebeleştirme ve Ölçme standardı uyarınca değer düşüklüğü karşılığı ayırarak net defter değerini sıfıra indirgediği \%1 katılım oranlı bir yatırımının gerçeğe uygun değeri nasıl hesaplanacaktır? (Yatırımın defter değeri yatırımcının finansal tablolarında önemli düzeyde değildir).

Yukarıdaki senaryolara göre her iki yatırımın da nispeten küçük katılım oranları ile izlenen yatırımlar olduğu görülmektedir. İlk bakışta bu yatırımların defter değerlerinin yatırımcının finansal tabloları için önemli düzeyde olmadığı görülmektedir. Ancak bu yatırımların gerçeğe uygun değerlerinin yatırımcının finansal tabloları için önemli düzeyde olup olmadığı bilinmemektedir. $\mathrm{Bu}$ nedenle mutlaka gerçeğe uygun değer ölçümü yapılmalıdır. Ancak Türkiye şartlarında bu ölçümün nasıl yapılacağı gerek yöntem olarak ve gerekse de yatırımcıya olan maliyeti açısından önemli bir problem olarak ortaya çıkmaktadır. $\mathrm{Bu}$ noktada düzenleyici otoritenin işletmelere yol gösterici bir düzenleme yapması gerektiği düşünülmektedir.

\section{KAYNAKLAR}

Özulucan, Abitter - Arslan, Seçkin - Keleş, Dursun (2017), "Menkul Kıymetlerin TMS 39 ve TFRS 9 Uyarınca Muhasebeleştirilmesi”, Ömer Halisdemir Üniversitesi İktisadi ve İdari Bilimler Fakültesi Dergisi, 10(4), Ekim, ss. 235 - 249. 
UFRS 9 Finansal Araçlar

UFRS 13 Gerçeğe Uygun Değer Ölçümü

UMS 24 İlişkili Taraf Açıklamaları

UMS 39 Finansal Araçlar: Muhasebeleştirme ve Ölçme 